\title{
Investigation on the reactivity of tetranuclear Group 7/8 mixed-metal clusters toward triphenylphosphine
}

Md. Rassel Moni a,b, Md. Jadu Mia a , Shishir Ghosh ${ }^{\text {a,*, }}$, Derek A. Tocher ${ }^{\text {c, }}$, Shaikh M.

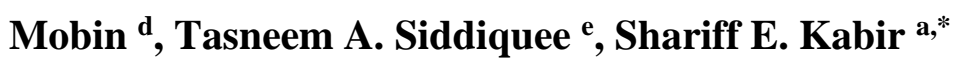

a Department of Chemistry, Jahangirnagar University, Savar, Dhaka 1342, Bangladesh

${ }^{\mathrm{b}}$ Department of Chemistry, Comilla University, Comilla-3506, Bangladesh

${ }^{\mathrm{c}}$ Department of Chemistry, University College London, 20 Gordon Street, London, WC1H OAJ, United Kingdom

${ }^{\mathrm{d}}$ Discipline of Chemistry, School of Basic Science, Indian Institute of Technology Indore, Khandwa Road, Indore 452 017, India

e Department of Chemistry, Tennessee State University, 3500 John A. Merritt Blvd., Nashville, TN 37209, USA

*Corresponding authors.

E-mail addresses: sghosh_006@yahoo.com (S. Ghosh); skabir_ju@yahoo.com (S.E. Kabir)

\begin{abstract}
Reactions of the tetranuclear mixed-metal clusters $\operatorname{ReM}_{3}(\mathrm{CO})_{13}\left(\mu_{3}\right.$-thpymS $)(\mathbf{1}, \mathrm{M}=\mathrm{Os} ; \mathbf{2}, \mathbf{M}$ $=\mathrm{Ru}$; thpymSH = tetrahydropyrimidine-2-thiol) with $\mathrm{PPh}_{3}$ are examined. At room temperature reaction between 1 and $\mathrm{PPh}_{3}$ in the presence $\mathrm{Me}_{3} \mathrm{NO}$ leads to the formation of mono- and bis-phosphine substituted clusters $\operatorname{ReOs}_{3}(\mathrm{CO})_{12}\left(\mathrm{PPh}_{3}\right)\left(\mu_{3}\right.$-thpymS) (3) and $\mathrm{ReOs}_{3}(\mathrm{CO})_{11}\left(\mathrm{PPh}_{3}\right)_{2}\left(\mu_{3}\right.$-thpymS) (4). Cluster 3 also reacts with $\mathrm{PPh}_{3}$ under similar conditions to give 4. In contrast, a similar reaction between 2 and $\mathrm{PPh}_{3}$ furnishes only the monophosphine substituted clusters $\mathrm{ReRu}_{3}(\mathrm{CO})_{12}\left(\mathrm{PPh}_{3}\right)\left(\mu_{3}\right.$-thpymS) (3). All the new clusters have been characterized by analytical and spectroscopic data together with single crystal X-ray diffraction for $\mathbf{1}, \mathbf{3}$ and $\mathbf{5}$.
\end{abstract}

Keywords: Mixed-metal clusters; Tetrahydropyrimidine-2-thiol; Carbonyls; Triphenylphosphine; X-ray structures. 


\section{Introduction}

Research on mixed-metal clusters has been spurred by the possible cooperative reactivity as a result of having two or more metal centers with different chemical properties in close proximity [1,2], which offer attractive perspective in stoichiometric and catalytic transformations [3-6]. Heterometallic systems may also combine the catalytic features of different metals to give novel reactivity that is inaccessible by homometallic systems [7]. We have reported systematic synthesis of a number of mixed-metal carbonyl clusters containing heterocyclic thiolate ligand(s) in the past few years [8-16]. For example, the Group 7/8 mixed-metal clusters of the general formula $\mathrm{MM}_{3}(\mathrm{CO})_{13}\left(\mu_{3}-\mathrm{L}\right)\left[\mathrm{M}=\mathrm{Mn}, \mathrm{Re} ; \mathrm{M}^{\prime}=\mathrm{Os}, \mathrm{Ru}\right.$; $\mathrm{L}-\mathrm{H}=$ nitrogen containing heterocyclic thiol] can be readily obtained from the direct reaction between $\mathrm{M}_{3}^{\prime}(\mathrm{CO})_{10-\mathrm{x}}(\mathrm{NCMe})_{\mathrm{x}}(\mathrm{x}=0,2)$ and $\mathrm{M}_{2}(\mathrm{CO})_{6}(\mu-\mathrm{L})_{2}$ in moderate to good yield (Scheme 1). The metallic core of these mixed-metal clusters forms a butterfly skeleton where the Group 7 metal (Mn or Re) always occupies a wingtip position [10-16]. The heterocyclic thiolate ligand is facially located on the convex side of the butterfly core that contains the Group 7 metal, but recent studies showed that it can also be shifted to the other face of the convex side by heating as shown in Scheme 1 [16].
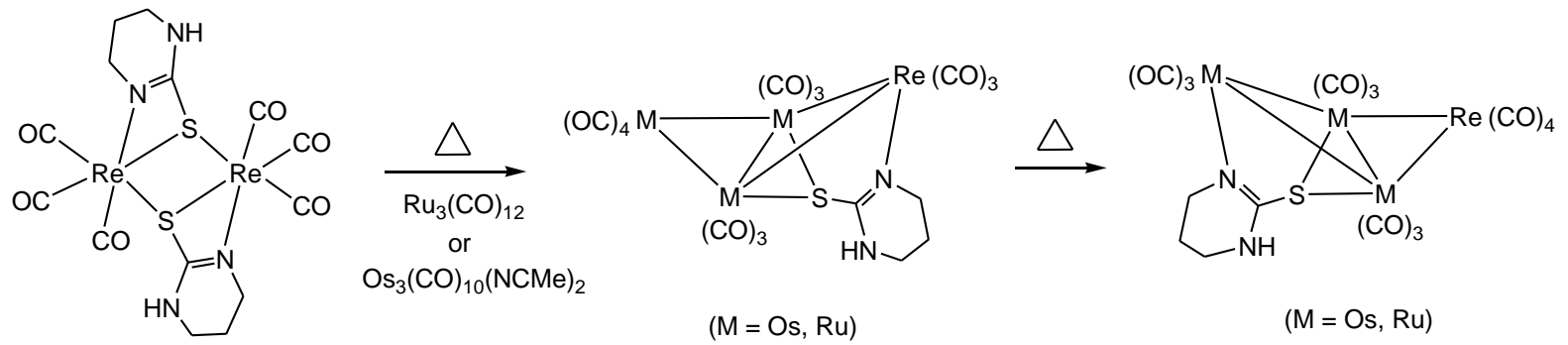

Scheme 1. Synthesis and thermally induced structural rearrangement of $\operatorname{ReM}_{3}(C O)_{13}\left(\mu_{3^{-}}\right.$ thpymS) $(\mathrm{M}=\mathrm{Os}, \mathrm{Ru})$.

Clusters having a butterfly arrangement of metal atoms are considered intermediate between tetrahedral and square-planar clusters $[17,18]$ which have been studied as intermediates in homogeneous catalytic processes [18,19], and also considered as a model for chemisorption of small molecules [20]. Although the $\mathrm{MM}_{3}{ }_{3}(\mathrm{CO})_{13}\left(\mu_{3}-\mathrm{L}\right)$ type butterfly clusters are relatively easy to prepare, studies on their reactivity toward various substrates has been almost neglected [12,13]. Tertiary phosphines $\left(\mathrm{PR}_{3}\right)$ are an important class of ligands in 
organometallic chemistry as their steric and electronic properties can easily be tuned in a systematic and predictable way over a very wide range by varying the $\mathrm{R}$ group(s) and they are also capable of stabilizing an exceptionally wide variety of metal complexes. Now we have investigated the reactions of two such mixed-metal clusters namely $\operatorname{ReOs}_{3}(\mathrm{CO})_{13}\left(\mu_{3^{-}}\right.$ thpymS) (1) and $\operatorname{ReRu}_{3}(\mathrm{CO})_{13}\left(\mu_{3}\right.$-thpymS) (2) with $\mathrm{PPh}_{3}$, the results of which will be reported herein.

\section{Experimental}

\subsection{General procedures}

All the reactions were carried out under a nitrogen atmosphere using standard Schlenk techniques unless otherwise noted. Reagent-grade solvents were dried using appropriate drying agents and distilled prior to use by standard methods. Clusters $\mathbf{1}$ and $\mathbf{2}$ were prepared according to the published procedures [16]. $\mathrm{PPh}_{3}$ was purchased from Sigma-Aldrich and used without further purification. $\mathrm{Me}_{3} \mathrm{NO} \cdot 2 \mathrm{H}_{2} \mathrm{O}$ was dried by azeotropic distillation using benzene with Dean-Stark distillation equipment. Products were separated in the air by TLC plates coated with $0.25 \mathrm{~mm}$ of silica gel (HF254-type 60, E. Merck, Germany). Infrared spectra were recorded on a Shimadzu IR Prestige-21 spectrophotometer. NMR spectra were recorded on a Varian Unity 500 NMR spectrometer. All chemical shifts are reported in $\delta$ units and are referenced to the residual protons of the deuterated solvent $\left({ }^{1} \mathrm{H}\right)$ and external $85 \% \mathrm{H}_{3} \mathrm{PO}_{4}\left({ }^{31} \mathrm{P}\right)$ as appropriate. Elemental analyses were performed by the Microanalytical Laboratories of Wazed Miah Science Research Centre at Jahangirnagar University.

\subsection{Reaction of $\operatorname{ReOs}_{3}(\mathrm{CO})_{13}\left(\mu_{3}\right.$-thpymS) (1) with $\mathrm{PPh}_{3}$}

$\mathrm{Me}_{3} \mathrm{NO}(6 \mathrm{mg}, 0.084 \mathrm{mmol})$ was added to a $\mathrm{CH}_{2} \mathrm{Cl}_{2}$ solution $(20 \mathrm{~mL})$ of $\mathbf{1}(50 \mathrm{mg}, 0.040$ $\mathrm{mmol})$ and $\mathrm{PPh}_{3}(21 \mathrm{mg}, 0.080 \mathrm{mmol})$ and the reaction mixture was then stirred at room temperature for $1 \mathrm{~h}$. The solvent was removed under reduced pressure and the residue chromatographed by TLC on silica gel. Elution with hexane/ $\mathrm{CH}_{2} \mathrm{Cl}_{2}(7: 3 \mathrm{v} / \mathrm{v})$ developed four bands. The first and second bands were unconsumed $\mathrm{PPh}_{3}(5 \mathrm{mg})$ and 1 (2 mg), respectively, whilst the third and fourth bands afforded $\operatorname{ReOs}_{3}(\mathrm{CO})_{12}\left(\mathrm{PPh}_{3}\right)\left(\mu_{3}\right.$-thpymS) $(3)(15 \mathrm{mg}, 25 \%)$ 
and $\operatorname{ReOs}_{3}(\mathrm{CO})_{11}\left(\mathrm{PPh}_{3}\right)_{2}\left(\mu_{3}\right.$-thpymS) (4) (32 mg 46\%) as red crystal after recrystalization from hexane $/ \mathrm{CH}_{2} \mathrm{Cl}_{2}$ at $4{ }^{\circ} \mathrm{C}$.

Data for 3: Anal. Calcd for $\mathrm{C}_{34} \mathrm{H}_{22} \mathrm{~N}_{2} \mathrm{O}_{12} \mathrm{Os}_{3} \mathrm{PReS}$ : C, 27.77; H, 1.51; N, 1.91. Found: C, 28.16; H, 1.57; N, 1.98\%. IR ( $\left.v_{\mathrm{CO}}, \mathrm{CH}_{2} \mathrm{Cl}_{2}\right): 2073 \mathrm{~m}, 2022 \mathrm{vs}, 1997 \mathrm{~s}, 1943 \mathrm{~m}, 1903 \mathrm{w} \mathrm{cm}{ }^{-1} .{ }^{1} \mathrm{H}$ $\operatorname{NMR}\left(\mathrm{CDCl}_{3}\right): \delta 7.47(\mathrm{~m}, 15 \mathrm{H}), 6.40(\mathrm{~s}, \mathrm{br}, 1 \mathrm{H}), 4.13(\mathrm{t}, \mathrm{J} 5 \mathrm{~Hz}, 2 \mathrm{H}), 3.21(\mathrm{~m}, 2 \mathrm{H}), 1.87(\mathrm{~m}$, $2 \mathrm{H}) .{ }^{31} \mathrm{P}\left\{{ }^{1} \mathrm{H}\right\} \mathrm{NMR}\left(\mathrm{CDCl}_{3}\right): \delta 7.0(\mathrm{~s})$.

Data for 4: Anal. Calcd for $\mathrm{C}_{51} \mathrm{H}_{37} \mathrm{~N}_{2} \mathrm{O}_{11} \mathrm{Os}_{3} \mathrm{P}_{2} \mathrm{ReS}$ : C, 35.93; H, 2.19; N, 1.64. Found: $\mathrm{C}$, 36.34; H, 2.25; N, 1.69\%. IR ( $v_{\mathrm{CO}}, \mathrm{CH}_{2} \mathrm{Cl}_{2}$ ): 2052m, 2010vs, 2005sh, 1976s, 19655w, 1936m, $1913 \mathrm{~m} \mathrm{~cm}^{-1} .{ }^{1} \mathrm{H}$ NMR(CDCl 3$): \delta 7.44$ (m, 4H), 7.34 (m, 26H), 6.34 (s, br, 1H), 4.19 (m, 2H), $3.30(\mathrm{~m}, 2 \mathrm{H}), 1.95(\mathrm{~m}, 2 \mathrm{H}) .{ }^{31} \mathrm{P}\left\{{ }^{1} \mathrm{H}\right\} \mathrm{NMR}\left(\mathrm{CDCl}_{3}\right): \delta 10.0(\mathrm{~d}, \mathrm{~J} 4 \mathrm{~Hz}, 1 \mathrm{P}), 6.5(\mathrm{~d}, \mathrm{~J} 4 \mathrm{~Hz}$, $1 \mathrm{P})$.

\subsection{Conversion of $\mathbf{3}$ to 4}

$\mathrm{A} \mathrm{CH}_{2} \mathrm{Cl}_{2}$ solution $(10 \mathrm{~mL})$ of $3(20 \mathrm{mg}, 0.014 \mathrm{mmol}), \mathrm{Me}_{3} \mathrm{NO}(1 \mathrm{mg}, 0.014 \mathrm{mmol})$ and $\mathrm{PPh}_{3}$ (4 mg, $0.015 \mathrm{mmol}$ ) was stirred at room temperature for $2 \mathrm{~h}$. A similar work up and chromatographic separation described above afforded 4 (16 mg, 69\%) after recrystallization from hexane $/ \mathrm{CH}_{2} \mathrm{Cl}_{2}$ at $4{ }^{\circ} \mathrm{C}$.

\subsection{Reaction of $\operatorname{ReRu}_{3}(\mathrm{CO})_{13}\left(\mu_{3}\right.$-thpymS) (2) with $\mathrm{PPh}_{3}$}

A $\mathrm{CH}_{2} \mathrm{Cl}_{2}$ solution $(20 \mathrm{~mL})$ of $2(40 \mathrm{mg}, 0.041 \mathrm{mmol}), \mathrm{PPh}_{3}(22 \mathrm{mg}, 0.084 \mathrm{mmol})$ and $\mathrm{Me}_{3} \mathrm{NO}(6 \mathrm{mg}, 0.084 \mathrm{mmol})$ was stirred at room temperature for $1 \mathrm{~h}$. The solvent was removed under reduced pressure and the residue separated by TLC on silica gel. Elution with hexane $/ \mathrm{CH}_{2} \mathrm{Cl}_{2}(7: 3 \mathrm{v} / \mathrm{v})$ developed six bands. The first and second bands were unconsumed $\mathrm{PPh}_{3}$ and 2, while the fourth band yielded $\mathrm{ReRu}_{3}(\mathrm{CO})_{12}\left(\mu_{3}\right.$-thpymS $)\left(\mathrm{PPh}_{3}\right)(5)(28 \mathrm{mg}, 56 \%)$ as red crystals after recrystallization from hexane $/ \mathrm{CH}_{2} \mathrm{Cl}_{2}$ at $4{ }^{\circ} \mathrm{C}$. The contents of the other three bands were too small for complete characterization.

Data for 5: Anal. Calcd for $\mathrm{C}_{34} \mathrm{H}_{22} \mathrm{~N}_{2} \mathrm{O}_{12} \mathrm{PRu}_{3} \mathrm{ReS}$ : C, 33.94; H, 1.84; N, 2.33. Found: C, 34.48; H, 1.91; N, 2.36\%. IR (v CO $\mathrm{CH}_{2} \mathrm{Cl}_{2}$ ): 2069m, 2022vs, 1996s, 1949m,br, 1903 w,br cm ${ }^{-}$ ${ }^{1} .{ }^{1} \mathrm{H} \mathrm{NMR}_{\left(\mathrm{CDCl}_{3}\right): \delta} 7.49(\mathrm{~m}, 15 \mathrm{H}), 6.51(\mathrm{~s}, \mathrm{br}, 1 \mathrm{H}), 4.03(\mathrm{t}, \mathrm{J} 5.6 \mathrm{~Hz}, 2 \mathrm{H}), 3.36(\mathrm{~m}, 2 \mathrm{H})$, $1.94(\mathrm{t}, \mathrm{J} 5.6 \mathrm{~Hz}, 2 \mathrm{H}) .{ }^{31} \mathrm{P}\left\{{ }^{1} \mathrm{H}\right\} \mathrm{NMR}\left(\mathrm{CDCl}_{3}\right): \delta 32.6$ (s).

\subsection{X-ray crystallography}


Single crystals suitable for single crystal X-ray diffraction analysis were grown by slow diffusion of hexane into a $\mathrm{CH}_{2} \mathrm{Cl}_{2}$ solution of $\mathbf{1 , 3}$ and 5 at $4{ }^{\circ} \mathrm{C}$. Suitable single crystals of $\mathbf{1}$ were mounted on an Agilent Super Nova dual diffractometer (Agilent Technologies Inc., Santa Clara, CA) (for 1) or Oxford Diffraction Super Nova diffractometer (for 3) using a Nylon Loop and the diffraction data were collected at 150(1) K using Mo-K $\alpha$ radiation $(\lambda=$ 0.71073). Unit cell determination, data reduction, and absorption corrections were carried out using CrysAlisPro [21]. The structures were solved with the ShelXS [22] structure solution program by direct methods and refined with ShelXL [23] (for 1) or XL [22] (for 3) refinement package using least squares minimisation within the OLEX2 [24] graphical user interface. Non-hydrogen atoms were refined anisotropically, and hydrogen atoms were included using a riding model. The selected crystal of $\mathbf{5}$ was attached to a MiTeGen loop by Apiezon $\mathrm{H}$ grease and mounted on a Rigaku Mercury375R/M CCD (XtaLAB mini) diffractometer using graphite monochromated Mo-K $\alpha$ radiation $(\lambda=0.71073)$ at $293(2) \mathrm{K}$. Data collection and subsequent data processing were performed using the available diffractometer software Crystal Clear (Rigaku). The data were corrected for Lorentz and polarization effects. The structure was solved by direct methods (SHELX-97) [25] and expanded by Fourier techniques. All non-hydrogen atoms were refined anisotropically and the hydrogen atoms were included using a riding model. Pertinent crystallographic parameters are given in Table 1.

\section{Results and discussion}

\subsection{Solid-state structure of 1}

Few years ago, we have reported the butterfly clusters $\operatorname{ReOs}_{3}(\mathrm{CO})_{13}\left(\mu_{3}\right.$-thpymS) (1) and $\operatorname{ReRu}_{3}(\mathrm{CO})_{13}\left(\mu_{3}\right.$-thpymS) (2) synthesized from the reactions between $\operatorname{Re}_{2}(\mathrm{CO})_{6}(\mu \text {-thpymS })_{2}$ and $\mathrm{Os}_{3}(\mathrm{CO})_{10}(\mathrm{NCMe})_{2}$ or $\mathrm{Ru}_{3}(\mathrm{CO})_{12}$ [16]. The solid-state molecular structure of 2 was also reported by us at that time, while we were unable to grow single crystals of $\mathbf{1}$ which was eventually characterized by elemental analysis and spectroscopic data only. Fortunately, we have obtained single crystals of $\mathbf{1}$ during the present study and carried out single crystal Xray diffraction studies, the results of which are shown in Fig. 1. As expected, the molecule consists of a butterfly core of four metal atoms with the rhenium at a wingtip position. The 
interplanar angle of the butterfly is $159.5^{\circ}$ and the thpymS ligand is located on the convex side by making bonds with the hinge osmium atoms and rhenium. It coordinates with rhenium using one of the ring nitrogen while bridges the hinge osmium atoms using the sulfur. The Os-Os [Os(1)-Os(3) 2.8596(3), Os(1)-Os(2) 2.8650(3) and Os(2)-Os(3) 2.7626(4) ̊̊], Os-Re [Re(1)-Os(3) 2.9249(3) and Re(1)-Os(2) 2.9307(3) Å], Re-N [2.181(5) $\AA]$ and Os-S [Os(2)-S(1) 2.4081(15) and Os(3)-S(1) 2.3979(16) ̊] bond distances are within the expected range and similar to those reported for related clusters $[12,13]$. The and bond distances

\subsection{Reactions of $\mathbf{1}$ and $\mathbf{2}$ with $P P h_{3}$ : Synthesis of phosphine-substituted mixed-metal clusters}

$\mathrm{Me}_{3} \mathrm{NO}$ initiated reactions between 1 and $\mathrm{PPh}_{3}$ at room temperature led to the isolation of mono- and bis-phosphine substituted clusters $\mathrm{ReOs}_{3}(\mathrm{CO})_{11}(\mu-\mathrm{CO})\left(\mathrm{PPh}_{3}\right)\left(\mu_{3}\right.$-thpymS $)(3)$ and $\operatorname{ReOs}_{3}(\mathrm{CO})_{11}\left(\mathrm{PPh}_{3}\right)_{2}\left(\mu_{3}\right.$-thpymS $)$ (5) in 25 and $46 \%$ yield, respectively, after chromatographic separation and workup. In separate experiments, we also found that $\mathbf{3}$ converted in to 4 upon treatment with $\mathrm{PPh}_{3}$ under similar conditions (Scheme 2).

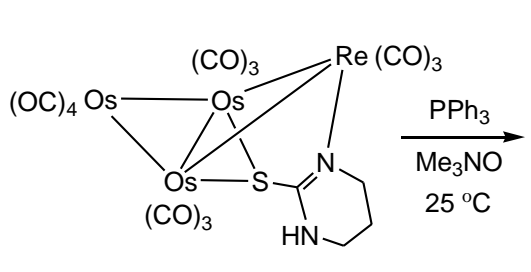

1

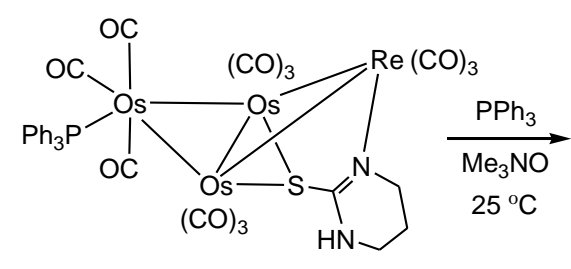

3

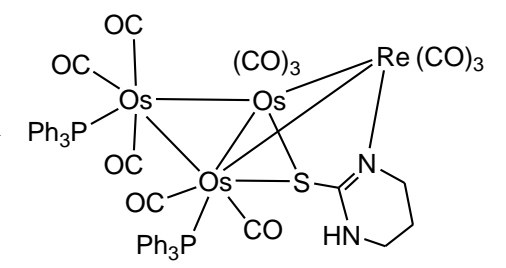

4

Scheme 2. Reaction of $\operatorname{ReOs}_{3}(\mathrm{CO})_{13}\left(\mu_{3}\right.$-thpymS) (1) with $\mathrm{PPh}_{3}$

The mono-phosphine substituted cluster $\mathbf{3}$ has been characterized structurally together with spectroscopic methods. The solid-state molecular structure of $\mathbf{3}$ is depicted in Fig. 2 with the captions containing selected bond lengths and angles. The cluster core is made up of four metal atoms, a rhenium and three osmium atoms, in its core making a butterfly skeleton where rhenium occupies a wingtip position. The thpymS ligand is facially located on its convex side in such a way that it is bonded to rhenium using one of the ring nitrogen atoms and bridges the hinge metal atoms through sulfur. The $\mathrm{PPh}_{3}$ ligand occupies one of the equatorial positions of the wingtip osmium as observed in the analogous cluster $\operatorname{ReOs}_{3}(\mathrm{CO})_{12}\left(\mathrm{PPh}_{3}\right)\left(\mu_{3}\right.$-pyS) (pySH = 2-mercatopyridine) [13]. The incoming phosphine 
ligand usually occupies one of the equatorial positions in $\mathrm{M}_{3}(\mathrm{CO})_{12}(\mathrm{M}=\mathrm{Os}, \mathrm{Ru}, \mathrm{Fe})$ to avoid nonbonding interaction with the axial carbonyls bound to other metal centers at the same face. But in these butterfly clusters, the carbonyls axially bonded to the hinge metals on their convex side had been removed by the bridging sulfur ligand. This factor together with the butterfly arrangement of the metal core makes enough space in these clusters for a phosphine ligand to be axially bound to the wingtip Group 8 metal on their convex side as observed in $\operatorname{ReOs}_{3}(\mathrm{CO})_{12}\left(\mathrm{PPh}_{3}\right)\left(\mu_{3}\right.$-mbt $)(\mathrm{mbtH}=2$-mercatobenzothiazole $)$ [12] (Chart 1). The triosmium wing of the butterfly in 3 [Os(1)-Os(3) 2.8807(4), Os(2)-Os(3) 2.9165(4), Os(1)-Os(2) 2.7618(3) ̊]] undergoes small expansion upon phosphine substitution as compared to 1 [Os(1)-Os(3) 2.8596(3), Os(1)-Os(2) 2.8650(3), Os(2)-Os(3) 2.7626(4) $\AA$ ] due to both steric and electronic reasons as expected, while the rhenium containing wing remains almost unaffected $[\operatorname{Re}(1)-O s(3) 2.9249(3), \operatorname{Re}(1)-O s(2) 2.9307(3) \AA$ for 1; $\operatorname{Re}(1)-$ Os(1) 2.9095(4), Re(1)-Os(2) 2.9591(4) ^ for 1]. The interplanar angle of the butterfly also increases slightly upon phosphine substitution $\left[161.2^{\circ}\right.$ in $3 ; 159.5^{\circ}$ in 1 ]. The Os-P bond distance of 2.3821(17) $\AA$ is quite similar to that observed in its pyridine-2-thiolate analogue $\operatorname{ReOs}_{3}(\mathrm{CO})_{12}\left(\mathrm{PPh}_{3}\right)\left(\mu_{3}-\mathrm{pyS}\right)$ [2.3487(7) $\AA$ ] [13], but is significantly shorter than that found in $\operatorname{ReOs}_{3}(\mathrm{CO})_{12}\left(\mathrm{PPh}_{3}\right)\left(\mu_{3}-\mathrm{mbt}\right)$ [2.496(2) $\AA$ ] [12] in which the phosphine occupies an axial coordination site on the wingtip osmium. The Re-N [2.201(6) $\AA$ ] and Os-S [2.3986(16) and 2.4053(17) $\AA$ ] bond distances are also very similar to those found in the parent cluster $\mathbf{1}$.
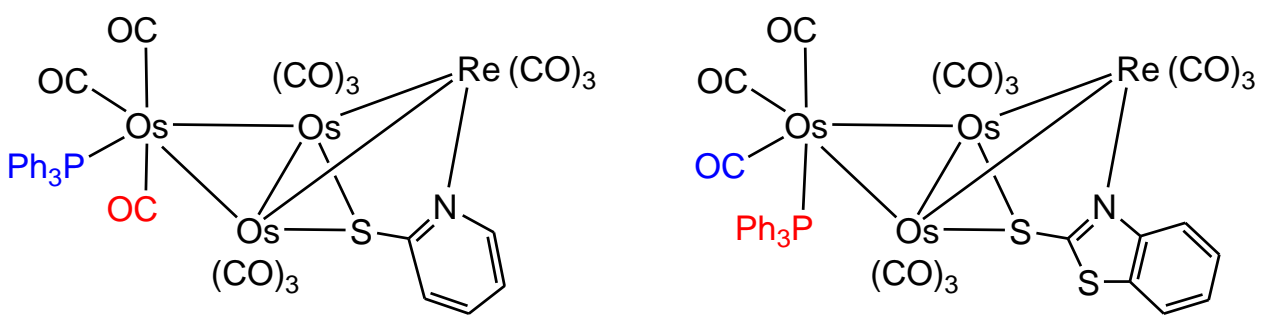

Chart 1. Coordination site occupied by $\mathrm{PPh}_{3}$ in $\mathrm{ReOs}_{3}(\mathrm{CO})_{12}\left(\mathrm{PPh}_{3}\right)\left(\mu_{3}\right.$-pyS $)$ [13] and

$$
\operatorname{ReOs}_{3}(\mathrm{CO})_{12}\left(\mathrm{PPh}_{3}\right)\left(\mu_{3}-\mathrm{mbt}\right)[12] \text {. }
$$

The solid-state structure of $\mathbf{3}$ persists in solution. The pattern of the IR spectra of $\mathbf{3}$ is very similar to that reported for analogous $\mathrm{ReOs}_{3}(\mathrm{CO})_{12}\left(\mathrm{PPh}_{3}\right)\left(\mu_{3}-\mathrm{pyS}\right)$ [13]. It shows separate sets of resonances in its ${ }^{1} \mathrm{H}$ NMR spectrum for thpymS and $\mathrm{PPh}_{3}$ ligands. It displays three resonances at $\delta 4.13,3.21$ and 1.87 , each integrates to $2 \mathrm{H}$, in the aliphatic region for the methylene protons of the thpymS ligand and a broad singlet at $\delta 6.40$ integrating to $1 \mathrm{H}$ for the 
$\mathrm{N}-\mathrm{H}$ proton of the same ligand. The phenyl protons of the $\mathrm{PPh}_{3}$ ligand appeared as a multiplet centered at $\delta 7.47$ in the aromatic region. Cluster 3 show only a singlet at $\delta 7.0$ in its ${ }^{31} \mathrm{P}\left\{{ }^{1} \mathrm{H}\right\}$ NMR spectrum due to the phosphorus of $\mathrm{PPh}_{3}$ ligand which is consistent with the solid-state structure.

Cluster 4 has been characterized by elemental analysis and spectroscopic data since repeated attempts to grow single crystals of this cluster were unsuccessful. The IR spectrum of $\mathbf{4}$ are very similar to those reported for crystallographically characterized analogous clusters $\operatorname{ReOs}_{3}(\mathrm{CO})_{11}\left(\mathrm{PPh}_{3}\right)_{2}\left(\mu_{3}\right.$-pyS $)$ [13] and $\mathrm{ReOs}_{3}(\mathrm{CO})_{11}\left(\mathrm{PPh}_{3}\right)_{2}\left(\mu_{3}-\mathrm{mbt}\right)$ [12] which contains two $\mathrm{PPh}_{3}$ ligands, one bonded to the wingtip osmium and the other coordinated to one of the hinge osmium atoms occupying an equatorial position on each osmium. The ${ }^{1} \mathrm{H}$ NMR spectra display three multiplets in the aliphatic region [ $\delta 4.19,3.30$ and 19.5], each integrating to $2 \mathrm{H}$, and a broad singlet at $\delta 6.34$ integrating to $1 \mathrm{H}$ for the methylene and $\mathrm{N}-\mathrm{H}$ protons of the thpymS ligand respectively. Separate sets of resonances have also been observed in the aromatic region of its ${ }^{1} \mathrm{H}$ NMR spectrum for the phenyl protons of the two $\mathrm{PPh}_{3}$ ligands. Cluster 4 also exhibits two equally intense doublets at $\delta 10.0$ and $6.5(\mathrm{~J} 4 \mathrm{~Hz})$ in its ${ }^{31} \mathrm{P}\left\{{ }^{1} \mathrm{H}\right\}$ NMR spectrum indicating the presence of two $\mathrm{PPh}_{3}$ ligands. The small $\mathrm{J}_{\mathrm{P}-\mathrm{H}}(4 \mathrm{~Hz})$ coupling constant indicates that the $\mathrm{PPh}_{3}$ ligands are bonded to different metal centers which is consistent with the proposed structure.

In contrast, we were able to isolate only the mono-phosphine substituted cluster $\mathrm{ReRu}_{3}(\mathrm{CO})_{12}\left(\mathrm{PPh}_{3}\right)\left(\mu_{3}\right.$-thpymS) (5) in 56\% yield from a similar reaction between 2 and $\mathrm{PPh}_{3}$. No bis-phosphine substituted tetranuclear butterfly cluster was isolated from this reaction. Cluster 5 has also been characterized by IR and NMR spectroscopic data together with single crystal X-ray diffraction analysis. The solid-state molecular structure of $\mathbf{5}$ is shown in Fig. 3, selected bond lengths and angles being listed in the caption. Akin to 3, the cluster contains a butterfly core of four metals, three ruthenium atoms and a rhenium, with rhenium occupying a wingtip position. The location as well as the coordination mode of the thpymS ligand are also similar i.e., it bridges the hinge ruthenium atoms using the sulfur while coordinates to rhenium using one of the ring nitrogen. The $\mathrm{PPh}_{3}$ ligand occupies one of the equatorial positions of the wingtip ruthenium as observed in 4 . The triruthenium wing of the butterfly in $5[\operatorname{Ru}(1)-\operatorname{Ru}(2)$ 2.8971(9), $R u(1)-\operatorname{Ru}(3)$ 2.7551(9), $\operatorname{Ru}(2)-\operatorname{Ru}(3)$ 2.8647(10) $\AA]$ are slightly bigger than that in the parent cluster $2[\mathrm{Ru}(1)-\mathrm{Ru}(2)$ 2.841(1), $\mathrm{Ru}(1)-\mathrm{Ru}(3)$ 2.760(1), $\mathrm{Ru}(2)-$ $\operatorname{Ru}(3)$ 2.847(1) $\AA$ ] [16] which can be explained as a consequences of carbonyl substitution by 
phosphine. The interplanar angle of the butterfly in $\mathbf{5}$ is $161.1^{\circ}$ which is slightly greater than that observed in the parent cluster 2 (159.5 ) [16] and the Ru-P bond distance of $2.3827(15)$ $\AA$ found in 5 is within the range reported in literature [9,26-28]. The Re-N [2.190(5) $\AA$ ] and $\mathrm{Ru}-\mathrm{S}[2.3796(16)$ and 2.3776(16) $\AA$ ] bond distances are very close to those observed in the

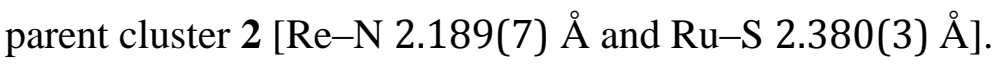

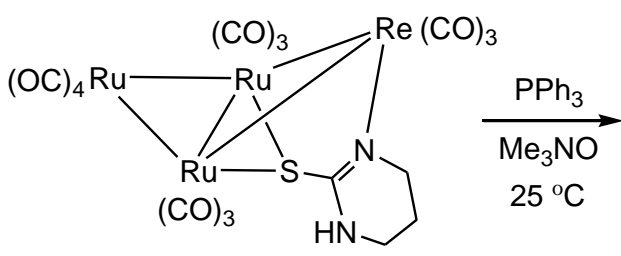

2

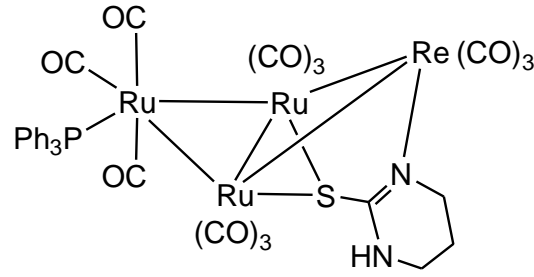

5

Scheme 3. Reaction of $\operatorname{ReRu}_{3}(\mathrm{CO})_{13}\left(\mu_{3}\right.$-thpymS) (2) with $\mathrm{PPh}_{3}$

The solution spectrocopic data of $\mathbf{5}$ indicates that the solid-state structure persists in solution. The ${ }^{1} \mathrm{H}$ NMR spectrum showed three resonances, each integrating to $2 \mathrm{H}$, centered at $\delta 4.03$, 3.36 and 1.94 and a broad singlet at $\delta 6.51$, integrating to $1 \mathrm{H}$, for the methylene and $\mathrm{N}-\mathrm{H}$ protons of the thpymS ligand, respectively. The spectrum also displays resonances in the aromatic region for the phenyl protons of the $\mathrm{PPh}_{3}$ ligand. In addition, the ${ }^{31} \mathrm{P}\left\{{ }^{1} \mathrm{H}\right\} \mathrm{NMR}$ spectrum exhibits only a singlet at $\delta 32.6$ due to the phosphorus of $\mathrm{PPh}_{3}$ which is in accord with the solid-state structure.

We also treated 5 with $\mathrm{PPh}_{3}$ under similar conditions in order to obtain the ruthenium analog of $\mathbf{4}$, but this resulted in the breakdown of the tetranuclear core. Two products were isolated from that reaction and their IR and NMR spectra were not very informative. Repeated attempts to grow singe crystals of these products were also unsuccessful. However, the ${ }^{1} \mathrm{H}$ and ${ }^{31} \mathrm{P}\left\{{ }^{1} \mathrm{H}\right\}$ NMR spectral data shows that none of these products contains two $\mathrm{PPh}_{3}$ ligands as observed in 4 . The interplanar angle of the butterfly observed in $3\left(161.2^{\circ}\right)$ and $5\left(161.1^{\circ}\right)$ are almost identical, so we may rule out the steric factor for this discrepancy in their reactions with $\mathrm{PPh}_{3}$. The real reason remains obscure from the present study and further works on their reactivity towards phosphines having different steric and electronic properties are currently ongoing in our laboratory to figure out the reason behind this discrepancy. 


\section{Conclusions}

In summary, we have investigated the reactions of two tetranuclear mixed-metal butterfly clusters $\mathrm{ReM}_{3}(\mathrm{CO})_{13}\left(\mu_{3}\right.$-thpymS $)(\mathbf{1}, \mathrm{M}=\mathrm{Os} ; \mathbf{2}, \mathrm{M}=\mathrm{Ru})$ with $\mathrm{PPh}_{3}$ in the presence of $\mathrm{Me}_{3}$ NO. Reaction between $\mathbf{1}$ and $\mathrm{PPh}_{3}$ afforded two phosphine-substituted clusters $\operatorname{ReOs}_{3}(\mathrm{CO})_{12}\left(\mathrm{PPh}_{3}\right)\left(\mu_{3}\right.$-thpymS) (3) and $\operatorname{ReOs}_{3}(\mathrm{CO})_{11}\left(\mathrm{PPh}_{3}\right)_{2}\left(\mu_{3}\right.$-thpymS) (4). In monosubstituted 3, the incoming $\mathrm{PPh}_{3}$ ligand occupies one of the equatorial coordination sites of the wingtip osmium, while the second $\mathrm{PPh}_{3}$ ligand is bound to one of the hinge osmium atoms in bis-substituted 4. Cluster 3 also reacted with $\mathrm{PPh}_{3}$ under similar conditions to give 4 which indicates the sequential formation of mono-and bis-phosphine substituted clusters during the reaction. In contrast, a similar reaction between 2 and $\mathrm{PPh}_{3}$ afforded only the monphosphine substituted cluster $\operatorname{ReRu}_{3}(\mathrm{CO})_{12}\left(\mathrm{PPh}_{3}\right)\left(\mu_{3}\right.$-thpymS $)(5)$. Attempts to synthesize the ruthenium analogue of $\mathbf{4}$ were unsuccessful which we suggest is due to the breakdown of the tetranuclear core when 5 was treated with $\mathrm{PPh}_{3}$ under similar conditions.

\section{Acknowledgments}

This research has been sponsored by the Ministry of Science and Technology, Government of the People's Republic of Bangladesh.

\section{Supplementary data}

CCDC 1818351, CCDC 1818354 and CCDC 1818355 contain supplementary crystallographic data for $\mathbf{1}, \mathbf{3}$, and $\mathbf{5}$, respectively. These data can be obtained free of charge via http://www.ccdc.cam.ac.uk/conts/retrieving.html, or from the Cambridge Crystallographic Data Centre, 12 Union Road, Cambridge CB2 1EZ, UK; fax: (+44) 1223336-033; or e-mail: deposit@ccdc.cam.ac.uk. 
Table 1. Crystal data and structure refinement details for compounds $\mathbf{1 ,} 3$ and $\mathbf{5}$

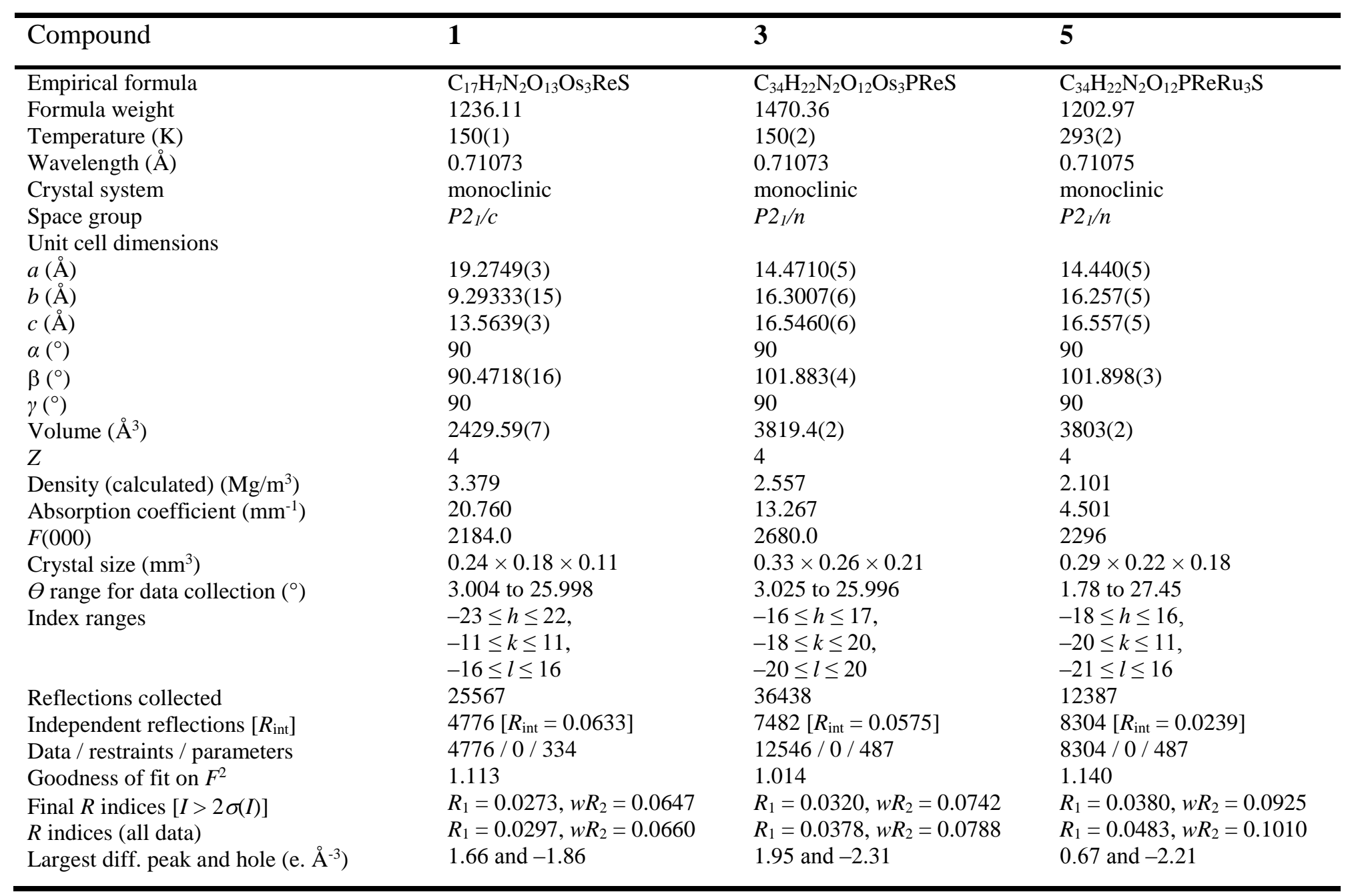




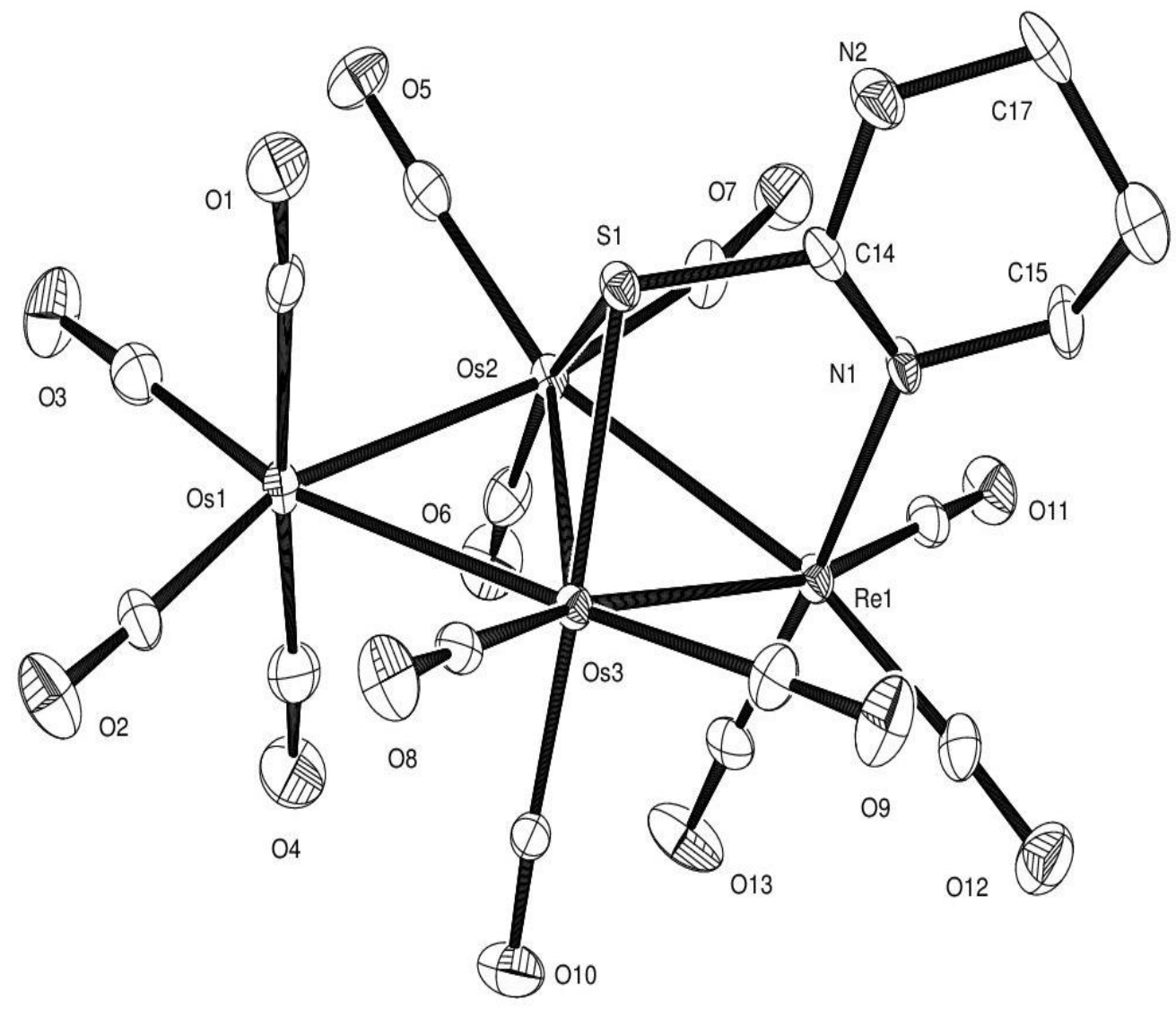

Fig. 1. The solid-state molecular structure of $\mathrm{ReOs}_{3}(\mathrm{CO})_{13}\left(\mu_{3}\right.$-thpymS) (1). Hydrogen atoms are omitted for clarity. Selected bond lengths $(\AA)$ and angles $\left(^{\circ}\right)$ : Os(1)-Os(3) 2.8596(3), Os(1)-Os(2) 2.8650(3), Os(2)-Os(3) 2.7626(4), Re(1)-Os(3) 2.9249(3), Re(1)-Os(2) 2.9307(3), Re(1)-N(1) 2.181(5), Os(2)-S(1) 2.4081(15), Os(3)$\mathrm{S}(1)$ 2.3979(16); N(1)-Re(1)-Os(3) 85.13(13), N(1)-Re(1)-Os(2) 84.72(12), S(1)-Os(2)-Re(1) 81.07(4), S(1)Os(2)-Os(3) 54.74(4), S(1)-Os(2)-Os(1) 81.78(4), Os(2)-S(1)-Os(3) 70.17(4), Os(3)-Os(1)-Os(2) 57.708(8), Os(3)-Os(2)-Os(1) 61.048(9), Os(2)-Os(3)-Os(1) 61.244(9), Os(3)-Re(1)-Os(2) 56.299(8), $\operatorname{Re(1)-Os(2)-~}$ Os(1) 119.536(11), Re(1)-Os(2)-Os(3) 61.745(9), Re(1)-Os(3)-Os(1) 119.917(11), Re(1)-Os(3)-Os(2) 61.956(9). 


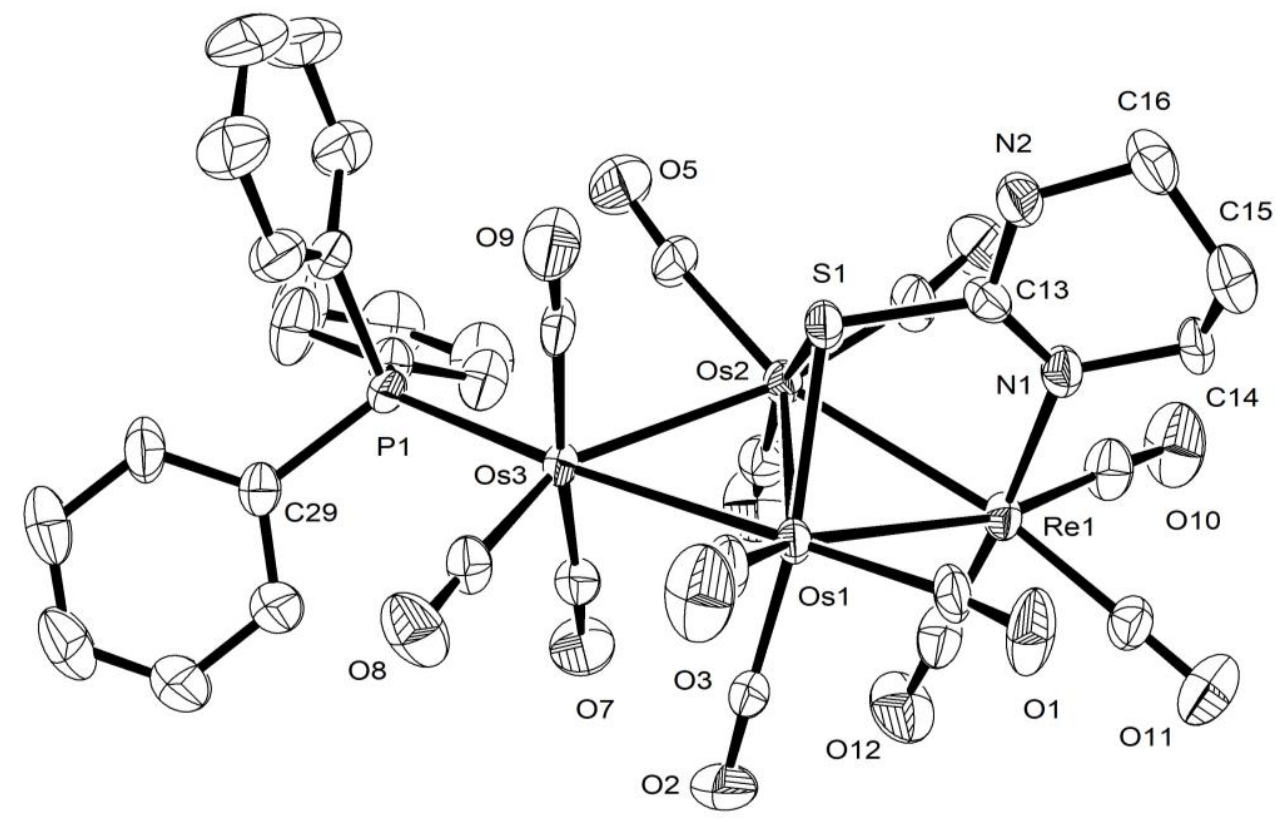

Fig. 2. The solid-state molecular structure of $\mathrm{ReOs}_{3}(\mathrm{CO})_{12}\left(\mathrm{PPh}_{3}\right)\left(\mu_{3}\right.$-thpymS $)(3)$. Hydrogen atoms are omitted for clarity. Selected bond lengths $(\AA)$ and angles $\left(^{\circ}\right)$ : Os(1)-Os(3) 2.8807(4), Os(1)-Os(2) 2.7618(3), Os(2)Os(3) 2.9165(4), Re(1)-Os(1) 2.9095(4), Re(1)-Os(2) 2.9591(4), Os(3)-P(1) 2.3821(17), Re(1)-N(1) 2.201(6), Os(2)-S(1) 2.4053(17), Os(1)-S(1) 2.3986(16); N(1)-Re(1)-Os(1) 85.12(15), N(1)-Re(1)-Os(2) 85.90(15), Os(1)-Re(1)-Os(2) 56.140(9), Os(3)-Os(1)-Os(2) 62.204(9), S(1)-Os(1)-Re(1) 81.24(4), S(1)-Os(1)-Os(3) 82.02(4), Os(1)-Os(2)-Os(3) 60.897(9), Re(1)-Os(2)-Os(1) 61.021(9), Re(1)-Os(2)-Os(3) 119.193(11), Os(2)-Os(3)-Os(1) 56.898(9), Os(2)-Os(1)-Re(1) 62.839(10), Os(3)-Os(1)-Re(1) 122.141(11), P(1)-Os(3)Os(2) 117.63(4), P(1)-Os(3)-Os(2) 174.50(4), P(1)-Os(3)-C(8) 91.6(2), P(1)-Os(3)-C(8) 89.4(2). 


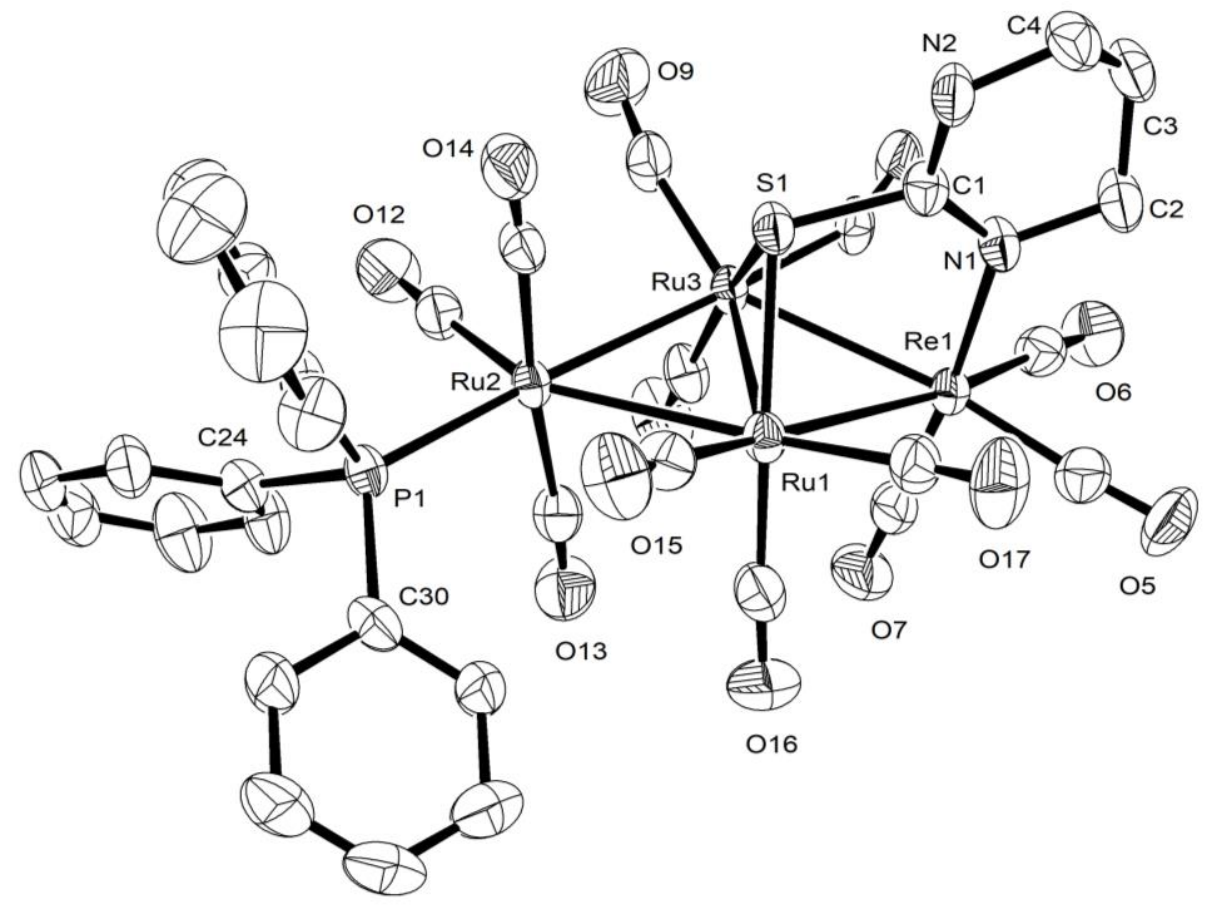

Fig. 3. The solid-state molecular structure of $\mathrm{ReRu}_{3}(\mathrm{CO})_{12}\left(\mathrm{PPh}_{3}\right)\left(\mu_{3}\right.$-thpymS) (5). Hydrogen atoms are omitted for clarity. Selected bond lengths( $\AA$ ) and angles $\left(^{\circ}\right)$ : $R u(1)-R u(2)$ 2.8971(9), $R u(1)-\operatorname{Ru}(3) 2.7551(9), \operatorname{Ru}(2)-$ $\mathrm{Ru}(3) \quad 2.8647(10), \quad \operatorname{Re}(1)-\operatorname{Ru}(1) \quad 2.9437(9), \quad \operatorname{Re}(1)-\operatorname{Ru}(3) \quad 2.9015(8), \quad \operatorname{Re}(1)-\mathrm{N}(1) \quad 2.190(5), \quad \operatorname{Ru}(1)-\mathrm{S}(1)$ 2.3796(16), Ru(3)-S(1) 2.3776(16), Ru(2)-P(1) 2.3827(15); N(1)-Re(1)-Ru(1) 86.13(11), Ru(3)-Ru(1)-Ru(2) 60.84(2), Ru(3)-Ru(2)-Ru(1) 57.13(2), Ru(1)-Ru(3)-Ru(2) 62.028(16), P(1)-Ru(2)-Ru(3) 176.03(4), Ru(2)$\mathrm{Ru}(3)-\operatorname{Re}(1) \quad$ 121.79(2), $\quad \mathrm{S}(1)-\mathrm{Ru}(1)-\mathrm{Ru}(3) \quad 54.58(4), \quad \mathrm{S}(1)-\mathrm{Ru}(1)-\operatorname{Re}(1) \quad$ 80.11(4), $\quad \mathrm{Ru}(3)-\operatorname{Ru}(1)-\operatorname{Re}(1)$ 61.108(16). 


\section{References}

[1] Selected reviews: (a) R.D. Adams, In Comprehensive Organometallic Chemistry II, E.W. Abel, F.G.A. Stone, G. Wilkinson, Eds. Elsevier, Oxford, 1995, Vol. 10, pp 1-22. (b) Y. Chi, D.K. Hwang, In Comprehensive Organometallic Chemistry II, E.W. Abel, F.G.A. Stone, G. Wilkinson, Eds. Elsevier, Oxford, 1995, Vol. 10, pp 85-185. (c) P. Braunstein, J. Rosé, In Comprehensive Organometallic Chemistry II, E.W. Abel, F.G.A. Stone, G. Wilkinson, Eds. Elsevier, Oxford, 1995, Vol. 10, pp 351-385.

[2] (a) L.H. Gade, Angew. Chem., Int. Ed. Engl., 2000, 39, 2658-2678. (b) M. Herberhold, G.-X. Jin, Angew. Chem., Int. Ed. Engl., 1994, 33, 964-966. (c) B. Bosnich, Inorg. Chem., 1999, 38, 2554-2562. (d) S. Liu, G.-X. Jin, Dalton Trans., 2007, 949-954. (e) Y.-Q. Chen, J. Zhang, S. Cai, X.-F. Hou, H. Schumann, G.-X. Jin, J. Chem. Soc., Dalton Trans., 2007, 749758. (f) J. N.L. Dennett, J. Jacke, G. Nilsson, A. Rosborough, M.J. Ferguson, M. Wang, R. McDonald, J. Takats, Organometallics, 2004, 23, 4478-4485.

[3] (a) R.D. Adams, B. Captain, M.D. Smith, Angew. Chem. Int. Ed., 2006, 45, 1109 1112. (b) R.D. Adams, B. Captain, L. Zhu, Inorg. Chem., 2006, 45, 430-436. (c) T. Tanase, R.A. Begum, Organometallics, 2001, 20, 106-114. (d) M.M. Dell'Anna, S. J. Trepanier, R. McDonald, M. Cowie, Organometallics, 2001, 20, 88-99. (e) P. Mathur, A.K. Das, M. Hossain, C.V.V. Satyanarayana, A.L. Rheingold, L.M. LiableSands, G.P.A. Yap, J. Organomet. Chem., 1997, 532, 189-199.

[4] (a) N. T. Lucas, J. P. Blitz, S. Petrie, R. Stranger, M. G. Humphrey, G. A. Health and V. Otieno-Alego, J. Am. Chem. Soc., 2002, 124, 5139-5153; (b) P. Mathur, A.K. Bhunia, S.M. Mobin, V.K. Singh, C. Srinivasu, Organometallics, 2004, 23, 3694-3700; (c) J.N. L. Dennett, S.A.R. Knox, K.M. Anderson, J.P.H. Charmant, A.G. Orpen, J. Chem. Soc., Dalton Trans., 2005, 63-73; (d) L. Quebatte, R. Scopelliti, K. Severin, Angew. Chem., Int. Ed., 2004, 43, 1520- 1524.

[5] (a) R.D. Adams, T.S. Barnard, Z. Li, W. Wu, J.H. Yamamato, J. Am. Chem. Soc., 1994, 116, 9103-9113; (b) R.D. Adams, T.S. Barnard, Organometallics, 1998, 17, 2567 2573; (c) R.D. Adams, T.S. Barnard, Organometallics, 1998, 17, 2885-2890; (d) A.J. Bridgeman, M.J. Mays, A.D. Woods, Organometallics, 2001, 20, 2932-2935.

(6) (a) Y. Ishii, M. Hidai, Catal. Today, 2001, 66, 53-61; (b) S. Gauthier, R. Scopelliti, K. Severin, Organometallics, 2004, 23, 3769-3771; (c) P. Braunstein, J. Rosé, In Catalysis by Di- and Polynuclear Metal Clusters, R.D. Adams, F. A. Cotton, Eds. Wiley: New York, 
1998; pp 443-508; (d) A.M. Trzeciak, J.J. Ziolkowski, Coord. Chem. Rev., 1999, 190-192, 883-900.

[7] (a) P. Kalck, Polyhedron, 1988, 7, 2441-2450; (b) E.K. Van den Beuken, B.L. Feringa, Tetrahedron, 1998, 54, 12985-13011; (c) P. Braunstein, J. Rosé, In Metal Clusters in Catalysis, P. Braunstein, L.A. Oro and P.R. Raithby, Eds.; Wiley-VCH, Weinheim, Germany, 1999, Vol. 2, pp 616-677.

[8] S. Ghosh, S.E. Kabir, S. Pervin, G.M.G. Hossain, D.T. Haworth, S.V. Lindeman, T.A. Siddiquee, D.W. Bennett, H.W. Roesky, Z. Anorg. Allg. Chem. 2009, 635, 76-87.

[9] A.K. Raha, S. Ghosh, I. Hossain, S.E. Kabir, B.K. Nicholson, G. Hogarth, L. Salassa, J. Organomet. Chem. 2011, 696, 2153-2160.

[10] S. Ghosh, S.E. Kabir, S. Pervin, A.K. Raha, G.M.G. Hossain, D.T. Haworth, S.V. Lindeman, T.A. Siddiquee, D.W. Bennett, L. Salassa, H.W. Roesky, Dalton Trans. 2009, 3510-3518.

[11] S.E. Kabir, J. Alam, S. Ghosh, K. Kundu, G. Hogarth, D.A. Tocher, G.M.G. Hossain, H.W. Roesky, Dalton Trans. 2009, 4458-4467.

[12] S. Ghosh, K.N. Khanam, M.K. Hossain, G.M.G. Hossain, D.T. Haworth, S.V. Lindeman, G. Hogarth, S.E. Kabir, J. Organomet. Chem. 2010, 695, 1146-1154.

[13] S. Ghosh, K.N. Khanam, G.M.G. Hossain, D.T. Haworth, S.V. Lindeman, G. Hogarth, S.E. Kabir, New J. Chem. 2010, 34, 1875-1884.

[14] S. Ghosh, F.K. Camellia, K. Fatema, M.I. Hossain, M.R. Al-Mamun, G.M.G. Hossain, G. Hogarth, S.E. Kabir, J. Organomet. Chem. 2011, 696, 2935-2942.

[15] S. Ghosh, M.S.A. Mia, E. Begum, G.M.G. Hossain, S.E. Kabir, Inorg. Chim. Acta 2012, $384,76-82$.

[16] M.F. Ahmad, J.C. Sarker, K.A. Azam, S.E. Kabir, S. Ghosh, G. Hogarth, T.A.

Siddiquee, M.G. Richmond, J. Organomet. Chem. 2013, 728, 30-37.

[17] P. R. Raithby and M. J. Rosales, Adv. Inorg. Chem. Radiochem., 1985, 29, 169-247.

[18] E. Sappa, A. Tiripicchio, A. J. Carty and G. E. Toogood, Prog. Inorg. Chem., 1987, 35, 437-625, and references therein.

[19] (a) A. Sivaramakrishna, H. S. Clayton, B. C. E. Makhubela and J. R. Moss, Coord. Chem., 2008, 252, 1460-1485. (b) I. Ojima, Z. Li, R. J. Donovan and P. Ingallina, Inorg. Chim. Acta, 1988, 270, 279-284. (c) V. Ferrand, G. Süss-Fink, A. Neels and H. StoeckliEvans, J. Chem. Soc., Dalton Trans., 1998, 3825-3831.

[20] E. L. Muetterties, T. N. Rhodin, E. Band, C. F. Brucker and W. R. Pretzer, Chem. Rev., 1979, 79, 91-137. 
[21] CrysAlisPro; Oxford Diffraction: Yarnton, England, 2015.

[22] G.M. Sheldrick, Acta Crystallogr., Sect. A: Found. Crystallogr. 64 (2008) 112-122.

[23] Sheldrick, G.M. (2015). Acta Cryst. C71, 3-8.

[24] O.V. Dolomanov, L.J. Bourhis, R.J. Gildea, J.aK. Howard, H. Puschmann, J. Appl. Crystallogr. 42 (2009) 339-341.

[25] G.M. Sheldrick, SHELXL-97, Program for Crystal Structure Refinement, University of Göttingen, 1997.

[26] (a) S. Ghosh, S. Rana, D.A. Tocher, G. Hogarth, E. Nordlander, S.E. Kabir, J. Organomet. Chem., 2009, 694, 3312-3319; (b) M. D. H. Sikder, S. Ghosh, S. E. Kabir, G. Hogarth, D. A. Tocher, Inorg. Chim. Acta, 2011, 376, 170-174; (c) S. Ghosh, G. Hogarth, S. E. Kabir, E. Nordlander, L. Salassa, D. A. Tocher, J. Organomet. Chem., 2011, 696, 19821989; (d) M. M. M. Khan, M. F. Ahmad, S. Rajbangshi, T. A. Siddiquee, S. Ghosh, S. E. Kabir, Polyhedron 2015, 101, 103-108.

[27] (a) M. I. Hossain, M. D. H. Sikder, S. Ghosh, S. E. Kabir, G. Hogarth, L. Salassa, Organometallics 2012, 31, 2546-2558; (b) M. K. Hossain, S. Rajbangshi, A. Rahaman, M. A. H. Chowdhury, T. A. Siddiquee, S. Ghosh, M. G. Richmond, E. Nordlander, G. Hogarth, S. E. Kabir, J. Organomet. Chem. 2014, 760, 231-239; (c) M. J. Hossain, S. Rajbangshi, M. M. M. Khan, S. Ghosh, G. Hogarth, E. Rosenberg, K. I. Hardcastle, M. G. Richmond, S. E. Kabir, J. Organomet. Chem. 2014, 767, 185-195.

[28] (a) M. M. Uddin, N. Begum, S. Ghosh, J. C. Sarker, D. A. Tocher, G. Hogarth, M. G. Richmond, E. Nordlander, S. E. Kabir, J. Organomet. Chem. 2016, 812, 197-206; (b) M. M. M. Khan, S. Ghosh, A. Rahaman, D. A. Tocher, M. G. Richmond, S. E. Kabir, J. Organomet. Chem. 2017, 843, 75-86; (c) S. Rajbangshi, S. Ghosh, G. Hogarth, S. E. Kabir, J. Clust. Sci. 2015, 26, 169-185. 


\section{Graphical Abstract}

Investigation on the reactivity of tetranuclear Group $7 / 8$ mixed-metal clusters toward triphenylphosphine

Md. Rassel Moni, Md. Jadu Mia, Shishir Ghosh, Derek A. Tocher, Shaikh M. Mobin, Tasneem A. Siddiquee, Shariff E. Kabir

The reactions of two tetranuclear mixed-metal clusters, $\operatorname{ReM}_{3}(\mathrm{CO})_{13}\left(\mu_{3}\right.$-thpymS $)(\mathrm{M}=\mathrm{Os}$, $\mathrm{Ru})$, with $\mathrm{PPh}_{3}$ have been investigated.

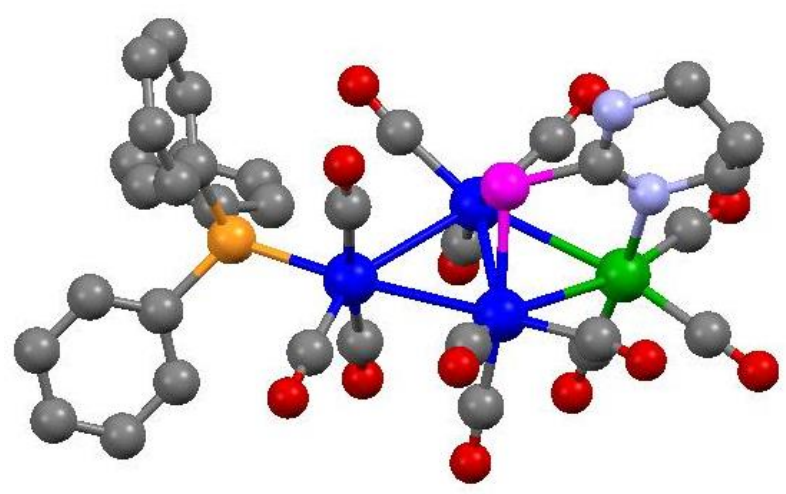

